\title{
PV array connected to the grid with the implementation of MPPT algorithms (INC, P\&O and FL method)
}

\author{
Oumnia Lagdani ${ }^{1}$, Mourad Trihi ${ }^{2}$, Badre Bossoufi ${ }^{3}$ \\ ${ }^{1,2}$ Laboratory for Renewable Energy and Dynamic Systems, University Hassan II, Faculty of Sciences Aïn Chock, \\ Casablanca, Morocco \\ ${ }^{3}$ LISTA Laboratory, Faculty of Sciences Dhar El Mahraz, University Sidi Mohammed Ben Abdellah, Fez, Morocco.
}

\begin{tabular}{|c|c|}
\hline Article Info & ABSTRACT \\
\hline Article history: & The purpose of this article is to extract the maximum power point at which \\
\hline Received Apr 17, 2019 & $\begin{array}{l}\text { the photovoltaic system can operate optimally. Ihe system considered is } \\
\text { simulated under different irradiations (between } 200 \mathrm{~W} / \mathrm{m}^{2} \text { and } 1000 \mathrm{~W} / \mathrm{m}^{2} \text { ), it }\end{array}$ \\
\hline Revised Jul 22, 2019 & mainly includes the established models of solar PV and MPPT module, a \\
\hline Accepted Aug 3, 2019 & $\begin{array}{l}\text { DC/DC boost converter and a DC / AC converter. The most common MPPT } \\
\text { techniques that will be studied are: "Perturbation and Observation" (P\&O) }\end{array}$ \\
\hline Keywords: & $\begin{array}{l}\text { method, "Incremental Conductance" (INC) method, and "Fuzzy Logic" (FL) } \\
\text { control. Simulation results obtained using MATLAB/Simulink are analyzed }\end{array}$ \\
\hline Photovoltaic System & \\
\hline
\end{tabular}

MPPT

Incremental Conductance

Method

Perturb And Observe Method

Fuzzy Logic Control Method

Copyright (C) 2019 Institute of Advanced Engineering and Science.

Simulation Results All rights reserved.

Corresponding Author:

Oumnia Lagdani,

Theoretical and Applied Physics Laboratory,

University Hassan II, Faculty of Sciences Aïn Chock,

Km 8 El Jadida Road, 20100 Casablanca, Morocco.

Email: oumnialagdani@gmail.com

\section{INTRODUCTION}

Renewable energy sources (RES) are part of the energy transition as a substitute for fossil fuels; they are the subject of renewed interest in recent years. Photovoltaic solar energy is among the renewable energies with the greatest potential for development, it attracts human attention because of its clean energy, cost reduction, continuity and reliability. However, the variation of power generation with atmospheric conditions is the major challenge of photovoltaic system applications and it's the main issue that must be taken in consideration. So, it is crucial to increase the efficiency of the photovoltaic (PV) system which should operate at the maximum power point [1]. However, the power generated by these panels varies continuously varying with weather conditions, which makes the power conversion efficiency very low (only about $15 \%$ of the energy converted by sun's light becomes electricity) [2].

More so, environmental factors such as solar radiance and ambient temperature significantly determine the energy amount that can be produced. Thus, an adequate MPPT is required by the control unit to reach the maximum power generated from the output PV array [3]. Several MPPT algorithms are proposed in the literature; some well-known are Perturb and Observe (P\&O), the Incremental Conductance (INC), Fractional open-circuit voltage (FVOC), Fractional short circuit current (FSC), artificial neural networks (ANN), Fuzzy logic (FL), etc [4-7].

Comparing the performance of these techniques seems a very interesting spot to determine which one is most suitable and efficient for a given PV system [8]. The purpose of the present paper is to study and 
compare the most appropriate maximum power point tracking (MPPT) methods for photovoltaic applications and assess their performances under irradiation changes using Incremental conductance method, Perturb and Observe method and Fuzzy Logic Control method.

A simulation study is designed to establish an implementation of 3 MPPT algorithms for PV modules connected to the electrical grid, giving a satisfactory response to the irradiation changes problem using MATLAB/Simulink software.

\section{MODELING OF THE PV SYSTEM}

The main elements of the solar photovoltaic system are grouped into five blocks as shown in Figure 1. It consists of a PV module, a DC/DC converter whose role is to make an impedance adaptation to ensure maximum energy independent of weather and load variations, a VSC converter, a three-phase transformer and a control system.

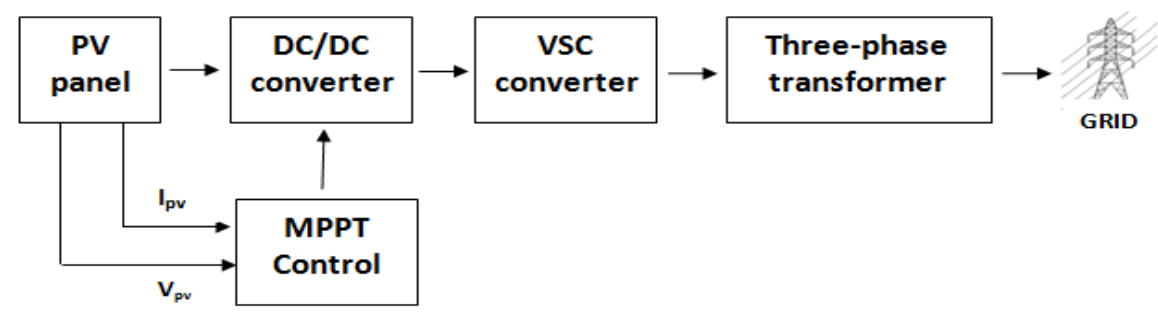

Figure 1. Diagram of a grid-connected PV system

\subsection{PV Solar Module}

A photovoltaic cell is made of semi-conductor materials and converts light energy directly into electrical energy. It is based on physical phenomenon called photovoltaic effect. To produce more power, the solar cell is assembled to form a module. The serial connections of several cells increase the voltage, while the implementation in parallel increase the current [9].

Electrically, each cell is represented as follows in Figure 2 [10]:

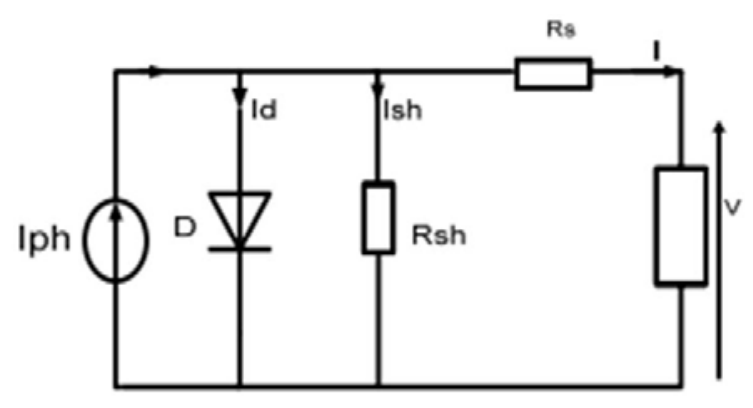

Figure 2. Photovoltaic cell equivalent circuit

The final equations of the photovoltaic panel model are:

$$
\begin{aligned}
& I_{p v}=I_{p h}-I_{d}-I_{s h} \\
& I_{p v}=I_{p h}-I_{0}\left(e^{\frac{q \times\left(V_{d}+I \times R_{S}\right)}{K \times T}}-1\right)-\frac{\left(V+I \times R_{S}\right)}{R_{S h}}
\end{aligned}
$$

with:

$$
I_{p h}=\left(I_{s c r}+K_{i} \times \Delta T\right) \times S
$$




$$
\begin{aligned}
& I_{d}=I_{0} \times N_{p p}\left(e^{\frac{}{q \times\left(V+I \times R_{S} \times\left(\frac{N_{S S}}{N p p}\right)\right)}}-1\right) \\
& I_{0}=I_{r r}\left(\frac{T_{c}}{T_{r}}\right)^{3} e\left(\frac{q E_{G}}{K n}\left(\frac{1}{T_{r}}-\frac{1}{T_{c}}\right)\right) \\
& I_{s h}=\left(\frac{V_{p v}+R_{S} \times \mathrm{I}_{\mathrm{pv}}}{R_{S h}}\right)
\end{aligned}
$$

Table 1. Expression of symbols

\begin{tabular}{ll}
\hline \multicolumn{2}{c}{ Used Parameters in above Equations } \\
\hline$V, I_{p v}$ Output Voltage, Current $(\mathrm{V}, \mathrm{A})$ & $I_{r r}$ Saturation Current at $T_{r}$ \\
$I_{p h}$ Light Generated Source & $S$ Solar Irradiance $\left(\mathrm{W} / \mathrm{m}^{2}\right)$ \\
$T_{c}$ Cell Temperature $(\mathrm{K})$ & $T_{r}$ Reference temperature \\
$I_{d}$ Diode Current & $n$ Ideality factor \\
$q$ Charge of an electron & $E_{G}$ Band-Gap Energy of the \\
$I_{s c r}$ Short-Circuit Current at Reference & material \\
Condition & $K$ Boltzmann's constant \\
$K_{i}$ Short-Circuit Temperature coefficient & $I_{0}$ Saturation current \\
$N_{p p}$ Number of cells in parallel & $N_{s S}$ Number of cells in series \\
\hline
\end{tabular}

The PV module adopted in this study is $100-\mathrm{kW}$ uses 330 SunPower modules (SPR-305E-WHT-D) consists of 96 polycrystalline silicon solar cells electrically configured as five series strings of 66 cells each [11]. The manufacturer specifications for one module are:

- Number of series-connected cells: 96.

- Open-circuit voltage: $\mathrm{Voc}=64.2 \mathrm{~V}$

- $\quad$ Short-circuit current: Isc $=5.96 \mathrm{~A}$.

- $\quad$ Current and voltage at maximum power: $\operatorname{Imp}=5.58 \mathrm{~A}, \mathrm{Vmp}=54.7 \mathrm{~V}$.

\subsection{Boost converter DC/DC}

The boost converter is also called a step-up converter it generates a higher output voltage than the input. The suggested converter in Figure 3 is similar to the classical boost converter, but differs only in the integration of a PID controller which is extensively used in many practical applications for better performance. It consists of an input voltage source, a switch, an inductor, a diode for protecting the PV module against negative current that could damage it and a capacitor [12].

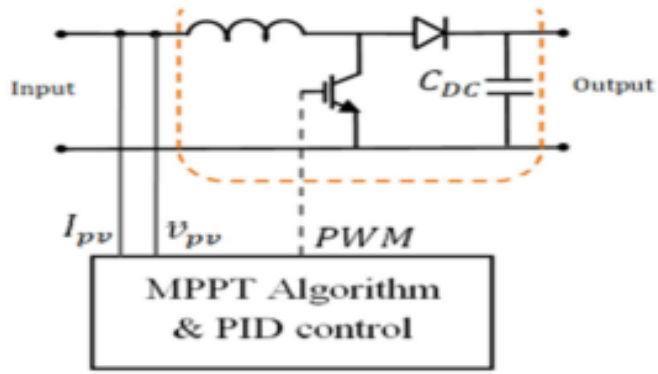

Figure 3. Boost Converter Modeling

\section{MAXIMUM POWER POINT TRACKING (MPPT)}

In the last two decades, numbers of different MPPT have been developed [13]. In our study, three MPPT techniques have been selected for the purpose of comparison:

- Incremental Conductance (INC)

- $\quad$ Perturbation and Observation (P\&O) 
- $\quad$ Fuzzy Logic (FL)

\subsection{Incremental Conductance (INC)}

The Incremental Conductance can determine if the MPPT has reached the MPP and stop disrupting the operating point.

It is based on the knowledge of the value of the conductance $G=\frac{I}{V}$ and on the increment of the conductance $\left(\mathrm{d} G=\frac{\mathrm{d} I}{\mathrm{~d} V}\right)$ to deduce the position of the operating point relative to the point of maximum power.

Figure 4 shows that the slope of the P-V power curve is zero at the MPP, increasing to the left of the MPP and decreasing to the right of the MPP.

The basic equations of this method are:

$$
\begin{aligned}
& \frac{\mathrm{d} I}{\mathrm{~d} V}=-\frac{I}{V} \text { at MPP } \\
& \frac{\mathrm{d} I}{\mathrm{~d} V}>-\frac{I}{V} \text { left of MPP } \\
& \frac{\mathrm{d} I}{\mathrm{~d} V}<-\frac{\mathrm{I}}{\mathrm{V}} \text { right of MPP }
\end{aligned}
$$

Where $I$ and $V$ are the PV array current and voltage respectively [14].

From (7) - (9), it is obvious that when the ratio of change of the conductance $(\mathrm{d} G)$ is greater than the opposite of the conductance $(-G)$, the duty cycle is decreased. On the other hand, if it is smaller than the opposite of the conductance $(-G)$, the duty ratio is increased. This process is repeated until reaching the point of maximum power [15]. The follow-up of the maximum power point requiring the procedure above is indicated in Figure 5.

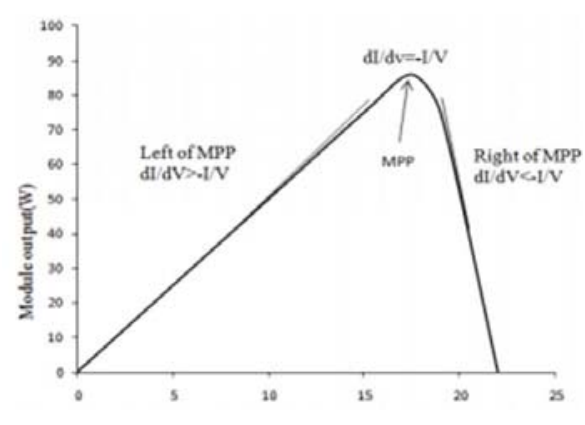

Figure 4. Basic idea of the Incremental Conductance method on a P-V curve of a Solar Module

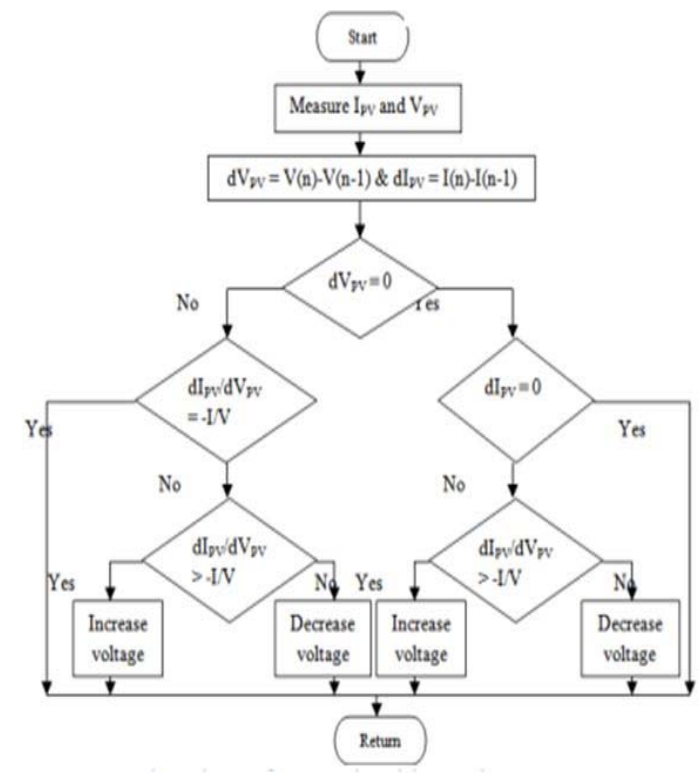

Figure 5. Organization chart of the INC algorithm

\subsection{Perturbation and Observation (P\&O)}

$\mathrm{P} \& \mathrm{O}$ algorithm are widely used in MPPT because of their simple structure and their few measured parameters which are required. As its name indicates, the concept of the algorithm is by increasing or decreasing the voltage of the PV array, then observing the effect of this change on the PV generated power [16]. The perturbation is continued in the same direction when the power increases due to the perturbation. After the peak power is reached the power at the MPP is zero and next instant decreases and hence after that, the perturbation reverses as shown in Figure 6 [17]. 


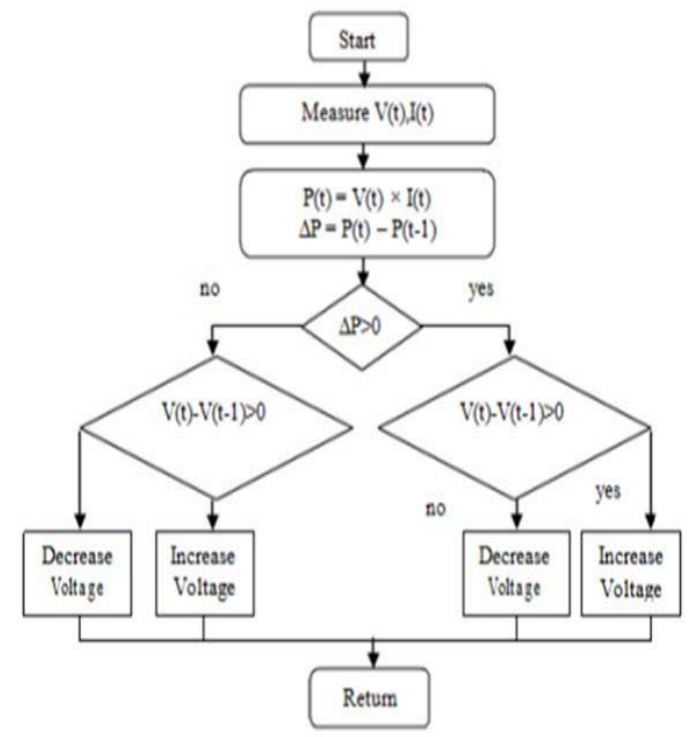

Figure 6. Organization chart of the $\mathrm{P} \& \mathrm{O}$ algorithm

\subsection{Fuzzy Logic (FL)}

Recently in PV systems, fuzzy logic controllers have been introduced in the tracking of the MPP.

They have the advantage to be robust and relatively simple to design as they do not require the knowledge of the exact model [18]. In particular, this command is better adapted to non-linear systems.

As represented in Figure 7 the operation of this algorithm is done in three blocks: fuzzification, inference and defuzzification.

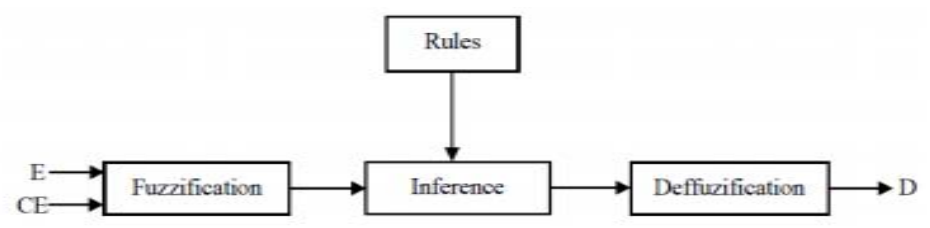

Figure 7. General scheme of a fuzzy controller

Fuzzification transforms input variables into linguistic variables or fuzzy variables.

The Fuzzy controller has two inputs and one output.

The two input variables are the E error and the CE error change defined by:

$$
\begin{aligned}
& E(k)=\frac{P_{p v}(k)-P_{p v}(k-1)}{V_{p v}(k)-V_{p v}(k-1)} \\
& C E(k)=E(k)-E(k-1)
\end{aligned}
$$

Where $P_{p v}(k)$ and $V_{p v}(k)$ are respectively the power and the voltage of the photovoltaic generator.

The input $E(k)$ shows if the operating point of the load at time $\mathrm{k}$ is located to the left or right of the point of maximum power on the PV characteristic, while the input $C E(k)$ expresses the direction of this point [19]. Figure 8 presents the Fuzzy inference using the Mamdani method, and defuzzification uses the center of gravity to calculate the output of the fuzzy controller which is the duty cycle [11]:

$$
D=\frac{\sum_{j=1}^{n} u(D j) D j}{\sum_{j=1}^{n} u(D j)}
$$


The control rules are shown in the table below with $E$ and $C E$ as inputs and $D$ as output.

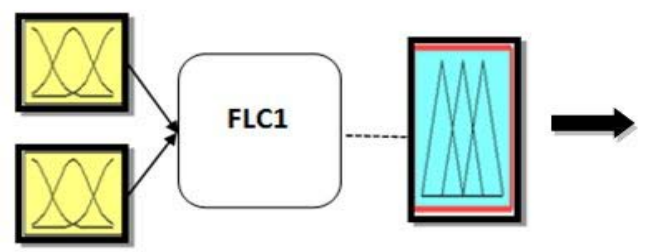

\begin{tabular}{|l|c|c|c|c|c|}
\hline \multicolumn{1}{|c|}{$C{ }^{-1}$} & $N B$ & $N S$ & $Z E$ & $P S$ & $P B$ \\
\hline NB & ZE & ZE & PB & PB & PB \\
\hline NS & ZE & ZE & PS & PS & PS \\
\hline ZE & PS & ZE & ZE & ZE & NS \\
\hline PS & NS & NS & NS & ZE & ZE \\
\hline PB & NB & NB & NB & ZE & ZE \\
\hline
\end{tabular}

Figure 8. Structure of inference rules

\section{SIMULATION AND RESULTS}

Our study is based on a $100-\mathrm{kW}$ photovoltaic generator that is connected to a $25 \mathrm{kV}$ grid via a DC-

DC boost converter and a three-phase voltage source converter (VSC).

Maximum Power Point Tracking (MPPT) is implemented in the boost converter by means of a Simulink model using different algorithms.

The studied model contains the following components:

- PV array delivering at $1000 \mathrm{~W} / \mathrm{m} 2$ sun irradiance a maximum of $100-\mathrm{kW}$.

- 5-kHz DC-DC Boost converter increasing voltage from PV natural voltage from $273 \mathrm{~V} \mathrm{DC}$ at maximum power to $500 \mathrm{~V} \mathrm{DC}$. The operating cycle of the switching is optimized by an MPPT controller which automatically varies the duty cycle to generate the voltage required to extract the maximum power.

- 3-level 3-phase VSC: The VSC converts the $500 \mathrm{~V}$ DC link voltage to $260 \mathrm{~V} \mathrm{AC}$ and keeps unity power factor. The VSC control system uses two control loops: an internal control loop which regulates Id and Iq grid currents and an external control loop which regulates DC link voltage to +/$250 \mathrm{~V}$. Id current reference is the output of the DC voltage external controller. To maintain unity power factor, Iq current reference is set to zero. The voltage outputs $\mathrm{Vd}$ and $\mathrm{Vq}$ of the current controller are converted into three modulation signals Uabc_ref used by the PWM generator.

- 10-kvar capacitor bank filtering harmonics produced by VSC.

- 100-kVA $260 \mathrm{~V} / 25 \mathrm{kV}$ three-phase coupling transformer.

- Utility grid (25-kV distribution feeder $+120-\mathrm{kV}$ equivalent transmission system).

\subsection{Simulation of grid connected PV module with INC as MPPT algorithm}

In this simulation, the PV array model contains an algebraic loop. This algebraic loop is required to get an accurate and iterative solution of the PV model when large sample times are used. The simulation of grid connected PV module with INC as MPPT algorithm result is shown Figure 9 to Figure 16.

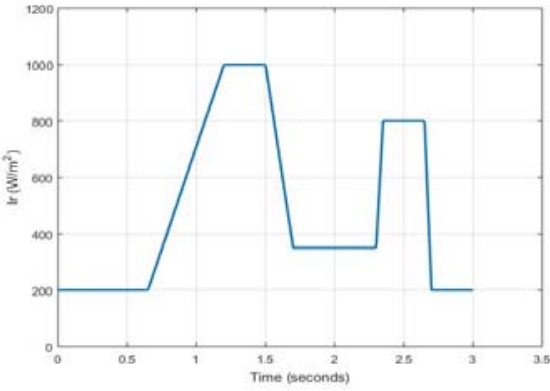

Figure 9. Variation of solar radiation vs time

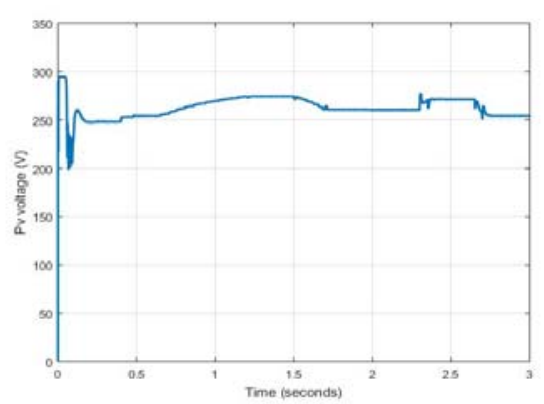

Figure 10. Variation of PV voltage vs time 


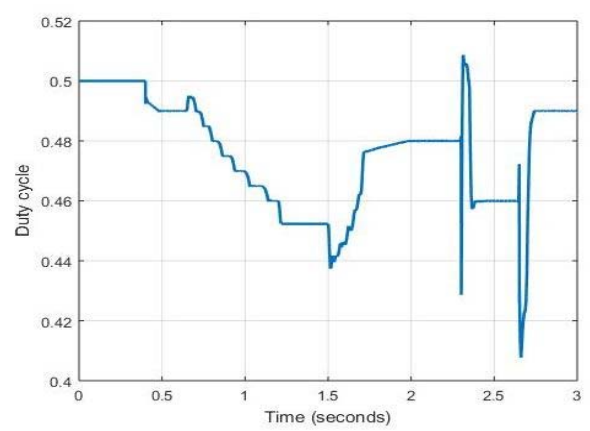

Figure 11. Variation of Duty Cycle vs time

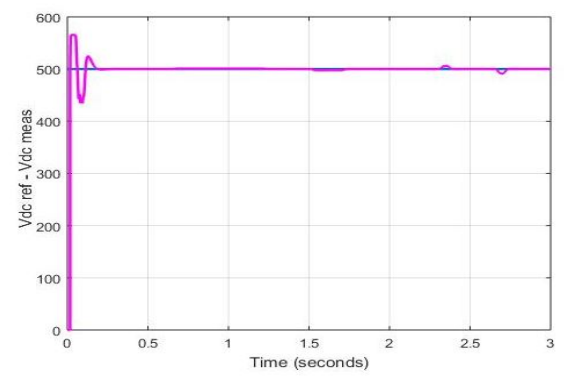

Figure 13. Measured Voltage and Reference Voltage vs time (Vdc ref - Vdc meas)

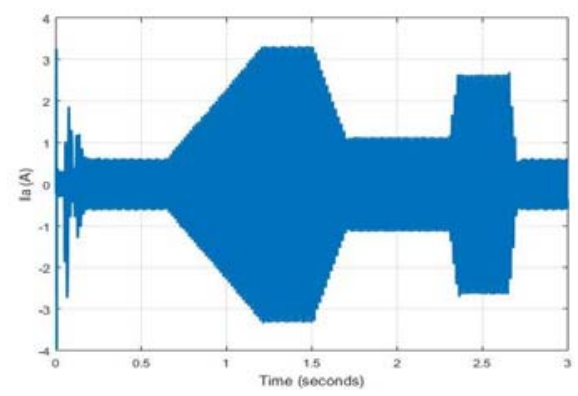

Figure 15 . Variation of voltage (Ia) at the utility grid vs time

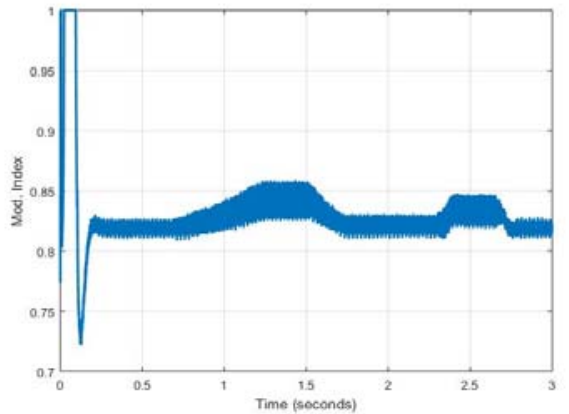

Figure 12. Modulation Index vs time (Mod.Index)

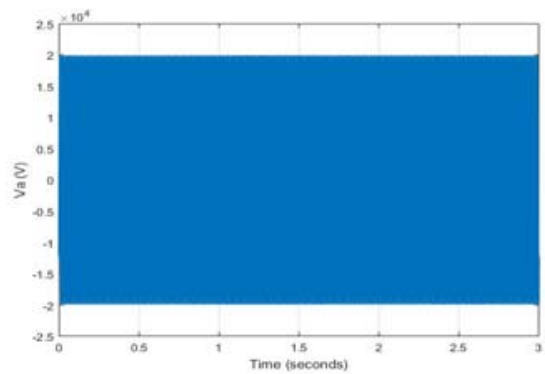

Figure 14. Variation of voltage (Va) at the utility grid vs time

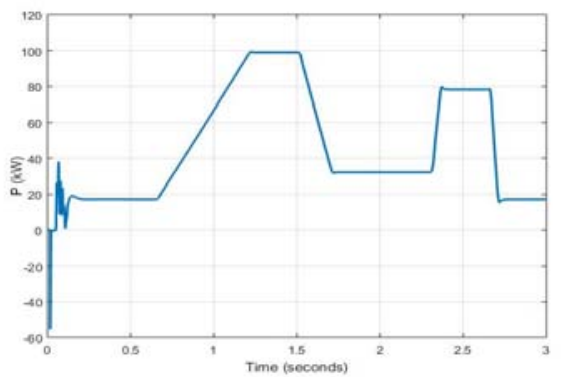

Figure 16. Variation of the power output at the utility grid vs time

\subsection{Simulation of grid connected $P V$ module with $P \& O$ as MPPT algorithm}

The main difference between this model and the previous model is in the way that DC-DC boost converter and three phases VSC are modeled. In this model, the boost and VSC converters are represented by equivalent voltage sources generating the average $\mathrm{AC}$ voltage over one cycle of the switching frequency.

This model allows using much larger time steps than the detailed model (50 microseconds v/s 1 microsecond), which allows a much faster simulation. The simulation of grid connected PV module with $\mathrm{P} \& \mathrm{O}$ as MPPT algorithmis shown Figure 17 to Figure 24. 


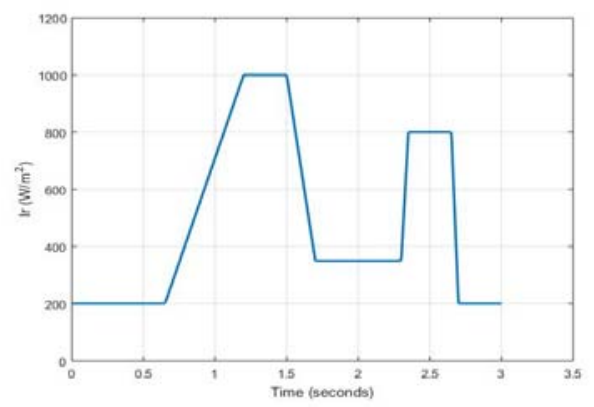

Figure 17. Variation of solar radiation vs time

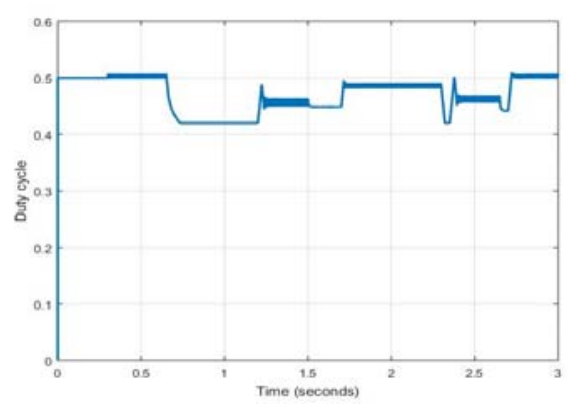

Figure 19. Variation of Duty Cycle vs time

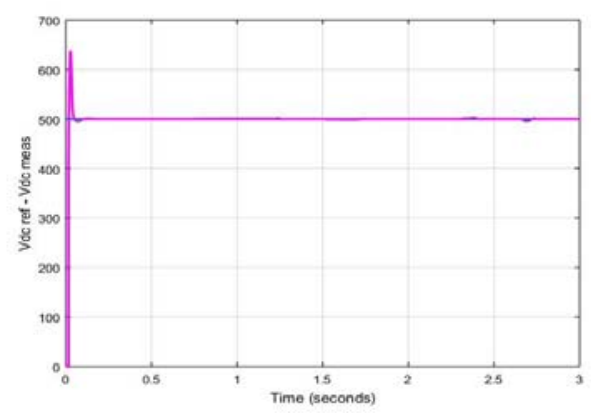

Figure 21. Measured Voltage and Reference Voltage vs time (Vdc ref - Vdc meas)

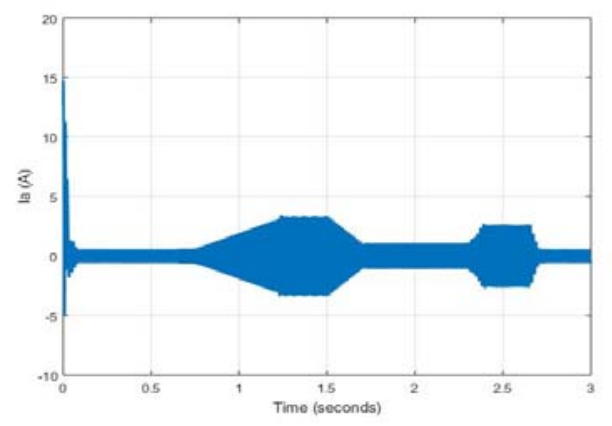

Figure 23. Variation of voltage (Ia) at the utility grid vs time

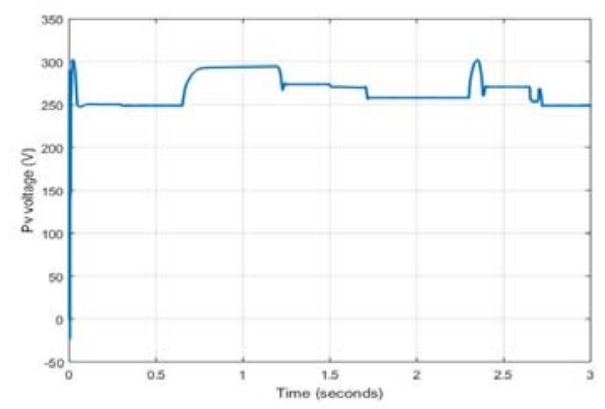

Figure 18. Variation of PV voltage vs time

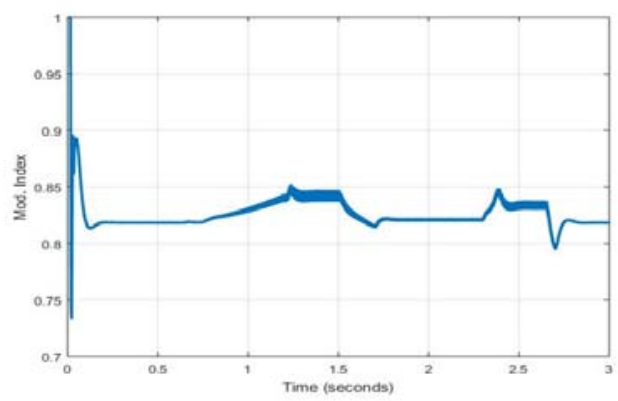

Figure 20. Modulation Index vs time (Mod.Index)

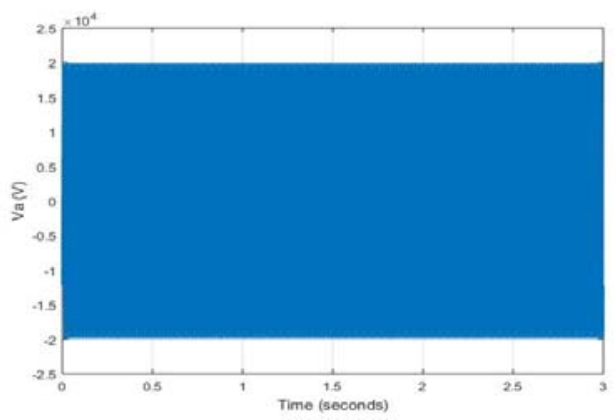

Figure 22. Variation of voltage (Va) at the utility grid vs time

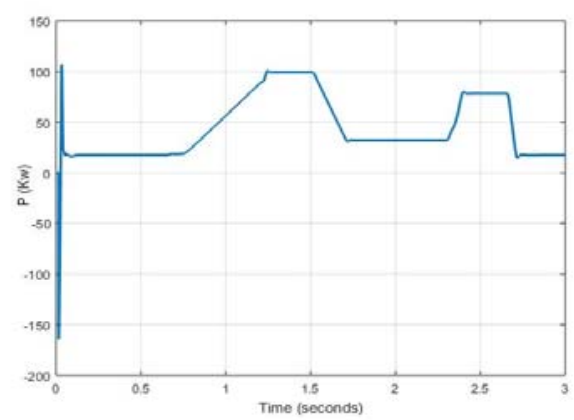

Figure 24. Variation of the power output at the utility grid vs time

\subsection{Simulation of grid connected PV module with LF as MPPT algorithm}


This simulation is the same one used when we simulated P\&O as MPPT algorithm. The result of the simulation is shown in Figure 25 to Figure 32.

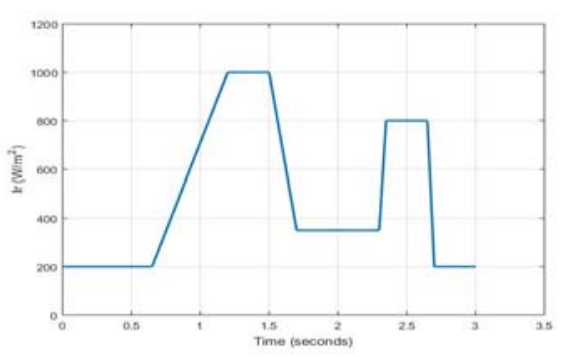

Figure 25. Variation of solar radiation vs time

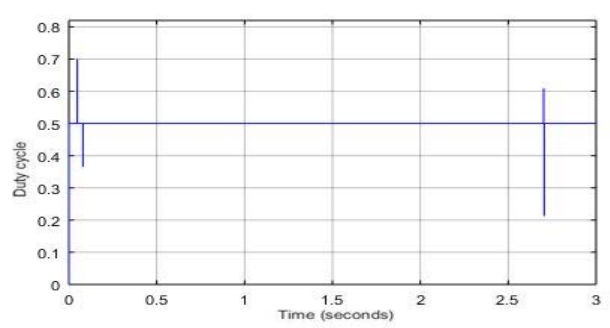

Figure 27. Variation of Duty Cycle vs time

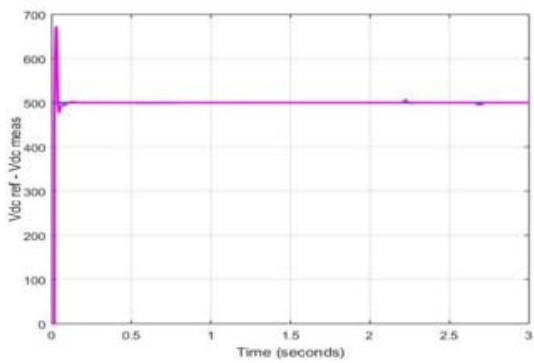

Figure 29. Measured Voltage and Reference Voltage vs time (Vdc ref - Vdc meas)

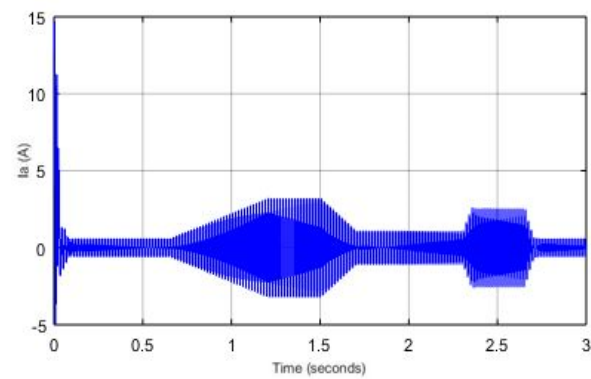

Figure 31. Variation of voltage (Ia) at the utility grid vs time

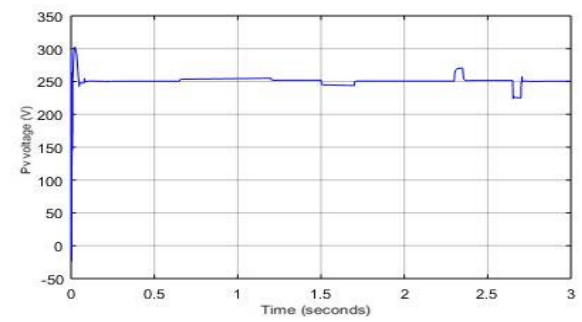

Figure 26. Variation of PV voltage vs time

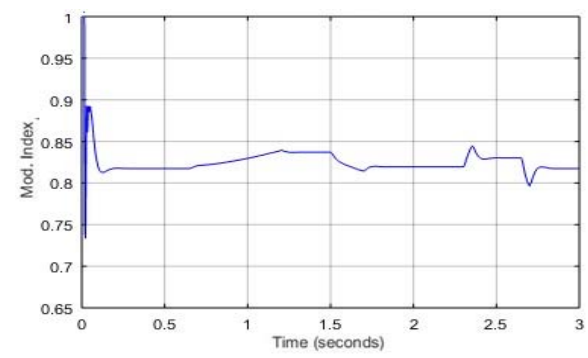

Figure 28. Modulation Index vs time (Mod.Index)

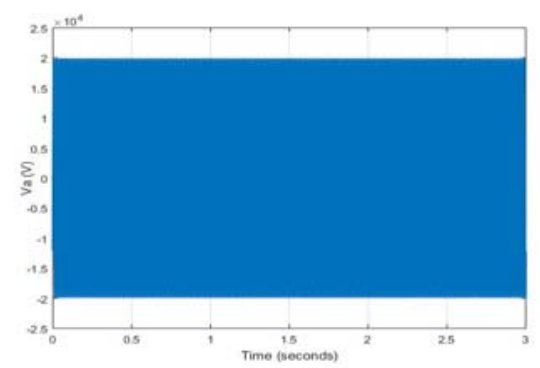

Figure 30. Variation of voltage (Va) at the utility grid vs time

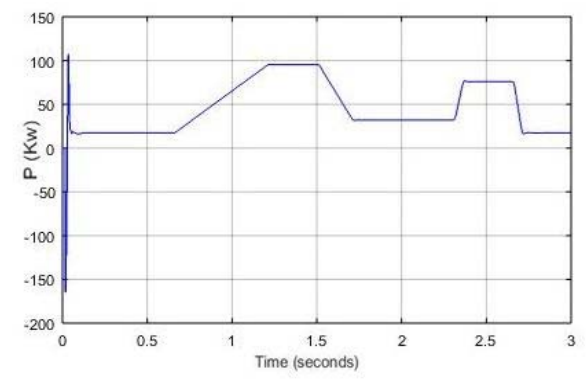

Figure 32. Variation of the power output at the utility grid vs time 


\section{COMPARATIVE STUDY OF RESULTS:}

Many algorithms are developed in order to maximize the efficiency of the PV system and to extract the maximum possible power from it. These algorithms differ in their efficiency, accuracy, reliability, and complexity.

The P\&O algorithm is often used for the reason that it is easy to implement. This strongly depends on the initial conditions and oscillations around the PPM because the search must be repeated periodically to force the system to oscillate around the PPM. From the simulation results shown above, it can be seen that $\mathrm{P} \& \mathrm{O}$ algorithm under cloudy skies had a significantly higher efficiency than incremental conductance.

The noticeable increase in the efficiency of the INC algorithm is due to its ability to overcome the disadvantages of the $\mathrm{P} \& \mathrm{O}$ algorithm, to follow fast atmospheric changes and avoid oscillations around the MPP. The output voltage using the INC method varies less when the atmospheric conditions vary rapidly and generate more power with the same variable illumination values as $\mathrm{P} \& \mathrm{O}$, but its development remains more complex.

The results obtained for this energy conversion system, show that by using the MPPT fuzzy controller, there is a compromise between rapidity in transient regime and stability in the steady state.

This command has very good performance; it is more flexible for nonlinear systems and allows to find the point of maximum power in a very short time compared to the other methods INC and P \& O.

It improves the responses of the photovoltaic system, not only does it reduce the response time at the point of maximum continuous power, but it also eliminates the fluctuations around this point and converges rapidly while reducing the power losses of the photovoltaic panel.

Referring to [20] and other works [21,22], our results are verified. It is proved that the Fuzzy Logic method has better performance than the other techniques, it is featured by a good rapidity and accuracy, but the main limitation of this algorithm is the complexity of implementation.

\section{CONCLUSION}

This paper describes the $100-\mathrm{kW}$ solar PV grid connected solar photovoltaic system designed in MATLAB/Simulink and observes the performance evaluation of the system. Solar PV system is taken as a primary resource.

The pursuit of the optimal point is well accomplished in all three cases, but in different ways, making one more optimal than the other.

It is shown that the overall power of the photovoltaic solar panel increases with the increase of the solar irradiation and the results obtained with a Fuzzy Controller are better than those obtained with INC and $\mathrm{P} \& \mathrm{O}$, it also proved that it has better performances, fast response time, very low steady-state error, and is robust to different variations in atmospheric conditions.

\section{REFERENCES}

[1] Hanen Abbes, Hafedh Abid, Kais Loukil, “An Improved MPPT Incremental Conductance Algorithm Using T-S Fuzzy System for Photovoltaic Panel”. International Journal of Renewable Energy Research, Vol.5, No.1, pp. 160$167,2015$.

[2] O. Ezinwanne, F. Zhongwen, \& L. Zhijun, "Energy Performance and Cost Comparison of MPPT Techniques for Photovoltaics and other Applications". Energy Procedia, Vol. 107, pp. 297-303, 2017.

[3] Ali Abdulwahhab Abdulrazzaq, Adnan Hussein Ali, "Efficiency Performances of Two MPPT Algorithms for PV System With Different Solar Panels Irradiances". International Journal of Power Electronics and Drive System (IJPEDS), Vol. 9, No. 4, pp. 1755-1764, December 2018,

[4] Abhishek Kumar Gupta and Ravi Saxena, "Review on widely-used MPPT Techniques for PV Applications". 1st International Conference on Innovation and Challenges in Cyber Security (ICICCS-INBUSH), pp. 270-273, February 2016

[5] H. Trabelsi, M. Elloumi, H. Abid and M. Kharrat, "MPPT controllers for PV array panel connected to Grid". 18th international conference on Sciences and Techniques of Automatic control \& computer engineering (STA), pp. 505$510,2017$.

[6] Salwa Assahout, Hayat Elaissaoui, Abdelghani El Ougli, Belkassem Tidhaf and Hafida Zrouri, "A Neural Network and Fuzzy Logic based MPPT Algorithm for Photovoltaic Pumping System". International Journal of Power Electronics and Drive System (IJPEDS), Vol. 9, No. 4, pp. 1823-1833, December 2018.

[7] E. N. Yaqin, A. G. Abdullah, D. L. Hakim and Nandiyanto, "MPPT based on Fuzzy Logic Controller for Photovoltaic System using PSIM and Simulink". The 2nd Annual Applied Science and Engineering Conference (AASEC), Vol.288, pp. 1-12, 2018.

[8] H. Abouobaida and EL Beid Said, "Practical Performance Evaluation of Maximum Power Point Tracking Algorithms in A Photovoltaic System". International Journal of Power Electronics and Drive System (IJPEDS), Vol. 8, No. 4, pp. 1744-1755, December 2017. 
[9] Othmane Salama, Abdelmoumen Tabyaoui and Mohamed Benchagra, "Control Methods on Three-phase Power Converters in Photovoltaic Systems". International Journal of Power Electronics and Drive System (IJPEDS), Vol. 9, No. 4, pp. 1851-1865, December 2018.

[10] A.S. Swathy and R. Archana, "Maximum Power Point Tracking Using Modified Incremental Conductance for Solar Photovoltaic System". International Journal of Engineering and Innovative Technology (IJEIT), Vol 3, Issue 2, pp. 333-337, August 2013.

[11] M. Lamnadi, M. TRIHI, B. Bossoufi and A. Boulezhar, "Comparative study of IC, P\&O and FLC method of MPPT algorithm for grid connected PV module". Journal of Theoretical and Applied Information Technology (JATIT), Vol.89. No.1, pp. 242-253, 15th July 2016.

[12] Mirza Fuad Adnan, Mohammad Abdul Moin Oninda, Mirza Muntasir Nishat, "Design and Simulation of a DC-DC Boost Converter with PID Controller for Enhanced Performance". International Journal of Engineering Research \& Technology (IJERT), Vol. 6, Issue 09, pp. 27-32, September 2017.

[13] Saleh Elkelani Babaa, Matthew Armstrong and Volker Pickert, "Overview of Maximum Power Point Tracking Control Methods for PV Systems". Journal of Power and Energy Engineering (JPEE), Vol.2 No.8, pp. 59-72, August 2014.

[14] M. Lokanadham and K.Vijaya Bhaskar, "Incremental Conductance Based Maximum Power Point Tracking (MPPT) for Photovoltaic System”. International Journal of Engineering Research and Applications (IJERA), Vol. 2, Issue 2, pp.1420-1424, Mar-Apr 2012

[15] N. Taribaa, A. Bouknadel, A. Haddou, N. Ikken, Hafsa El Omari and Hamid El Omari, "Comparative Study of Adaptive Controller Using MIT Rules and Lyapunov Method for MPPT Standalone PV Systems". AIP Conference Proceedings, Vol. 1801, Issue 1, 2017.

[16] Mohammed Slimi, Abdelkrim Boucheta and Bousmaha Bouchiba, "Maximum power control for photovoltaic system using intelligent strategies". International Journal of Power Electronics and Drive System (IJPEDS), Vol. 10, No. 1, pp. 423-432, March 2019.

[17] Ahmed M. Atallah, Almoataz Y. Abdelaziz, and Raihan S. Jumaah, "Implementation of perturb and observe MPPT of PV system with direct control method using buck and buck boost converters". Emerging Trends in Electrical, Electronics \& Instrumentation Engineering: An international Journal, Vol. 1, No. 1, February 2014

[18] M.S. Aït Cheikh, C. Larbes, G.F. Tchoketch Kebir and A. Zerguerras, "Maximum power point tracking using a fuzzy logic control scheme". Revue des Energies Renouvelables, Vol. 10, N. 3, pp. 387-395, 2007.

[19] F.Bouchafaaa, I. Hamzaouia and A. Hadjammar, "Fuzzy Logic Control for the tracking of maximum power point of a PV system". Energy Procedia, Vol. 6, pp. 633-642, 2011.

[20] N. Zinelaabidine, M. Karim, B. Bossoufi \& M. Taoussi, "MPPT algorithm control for grid connected PV module". International Conference on Advanced Technologies for Signal and Image Processing (ATSIP), May 2017.

[21] V. Venkata Swathi, G. Chandra Sekhar and P.V.V. Pawan kumar, "Design and Simulation of 100kw Grid Connected Solar PV System Using MATLAB/Simulink". International Journal of Innovative Research in Science, Engineering and Technology (IJIRSET), Vol. 7, Issue 9, pp. 9372-9380, September 2018.

[22] Arvind Kumar, Manoj Kumar, Dattatraya H. Nagaraj, Amanpreet Singh and Jayanthi Prattapati, "Comparative Study of IC and Perturb and Observe Method of MPPT Algorithm for Grid Connected PV Module". World Academy of Science, Engineering and Technology International Journal of Electrical and Computer Engineering, Vol. 8, No. 7, pp. 1225-1233, 2014.

Int J Pow Elec \& Dri Syst Vol. 10, No. 4, Dec 2019 : 2084 - 2095 


\section{BIOGRAPHIES OF AUTHORS}

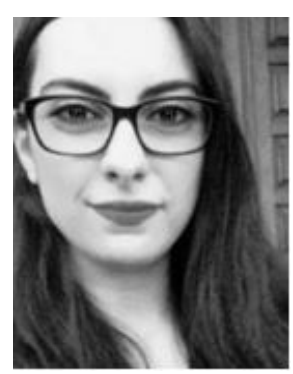

Oumnia LAGDANI was born in Casablanca, Morocco, on October 17, 1994. She received her Master degree in Renewable Energies and Energy Systems from Hassan II University, Faculty of Sciences Ain Chock - Casablanca, Morocco in 2017. Her current research works include the development of renewable energy system, electric motor drives and power electronics.

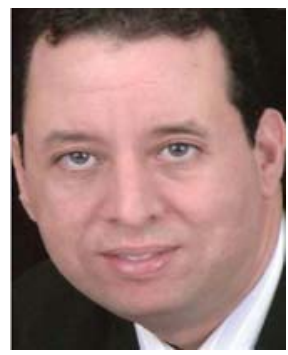

Mourad TRIHI was born in Casablanca, Morocco, on December 25, 1967. He is a Professor in Physics at University Hassan II of Casablanca, Faculty of Science Aïn Chock and member in the Laboratory of Theoretical and Applied Physics. He received the Ph.D. degree in Biophysics from University of Limoges, France in 1995 and a second state thesis in Physics at University Hassan II of Casablanca in 2001.

In 1991 he received the Diploma of Advanced Studies from University of Clermont Ferrand in Physics. He is now national representative of African Network for Solar Energy in Morocco.

His main areas of interests include renewable energy, multi sources energy, electrical motor drives, electrical power, FPGA and energy conversion.

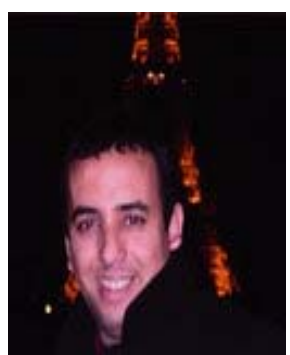

Badre BOSSOUFI was born in Fez city, Morocco, on May 21, 1985. He was an Assistant Professor of Electrical Engineering, at the Higher School of Technologies, Oujda Morocco, in 2013. He received the Ph.D. degree in Electrical Engineering from University Sidi Mohammed Ben Abdellah, Faculty of Sciences, Morocco and PhD. degree from University of Pitesti, Faculty of Electronics and Computer, Romanie and Montefiore Institute of electrical engineering, Luik, Belgium, in 2012. He received the MASTER degree in industrial electronics from the Faculty of Sciences-Fez, in 2009. His research interests include static converters, electrical motor drives, power electronics, smart grid, renewable energy and artificial intelligence. 